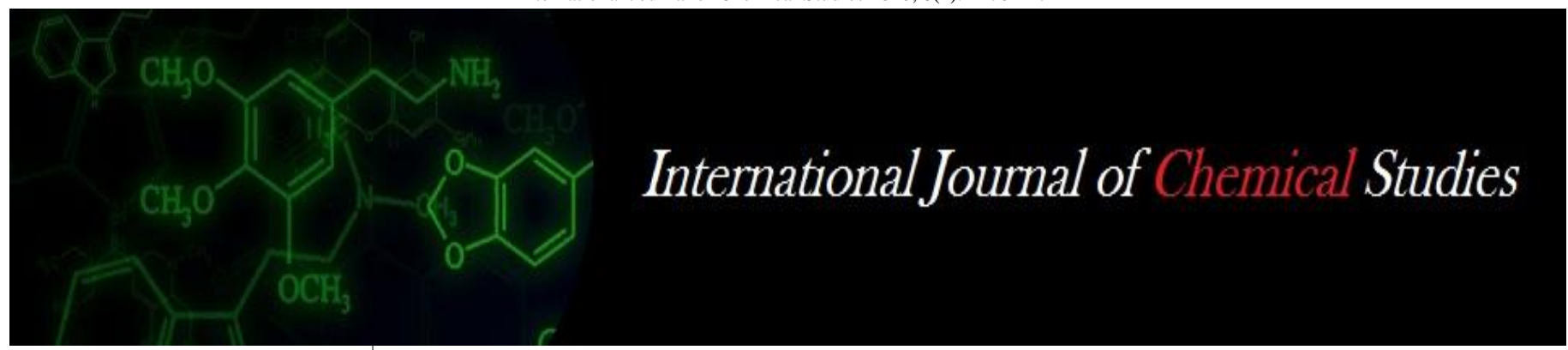

P-ISSN: 2349-8528

E-ISSN: 2321-4902

IJCS 2020; 8(1): 1170-1174

(C) 2020 IJCS

Received: 13-11-2019

Accepted: 15-12-2019

Bhorania Nirali Chandulal

Department of Soil Science and

Agricultural Chemistry

College of Agriculture

Junagadh Agricultural

University, Junagadh, Gujarat, India
Corresponding Author: Bhorania Nirali Chandulal Department of Soil Science and Agricultural Chemistry College of Agriculture Junagadh Agricultural University, Junagadh, Gujarat, India

\section{Effect of saline irrigation water on yield, quality and biochemical parameter of chickpea (Cicer arietinum $\mathbf{L}$.) varieties}

\author{
Bhorania Nirali Chandulal
}

DOI: https://doi.org/10.22271/chemi.2020.v8.i1p.8410

\begin{abstract}
A pot experiment was conducted at Department of Soil Science and Agricultural Chemistry, College of Agriculture, JAU, Junagadh to assess the "Effect of saline irrigation water on yield, quality and biochemical parameter of chickpea (Cicer arietinum L.) varieties" during the winter, season of 2016-17. The pot experiment comprised four levels of salinity viz., <2.0, 4.0, 6.0 and $8.0 \mathrm{dS} \mathrm{m}^{-1}$ and five different varieties viz., $\mathrm{V}_{1}$ - GG-2, V V $^{-}$GJG-3, $\mathrm{V}_{3}-\mathrm{GG}-5, \mathrm{~V}_{4}$ - GJG-6 and $\mathrm{V}_{5}$ - Dahod Yellow. The highest seed yield (12.28 g plant $\left.^{-1}\right)$ and stalk yield $\left(20.55 \mathrm{~g} \mathrm{plant}^{-1}\right)$ were observed with variety $\mathrm{V}_{4}$ (GJG-6). The effect of varieties on quality parameters like Test weight -100 seeds gave significant result but in protein content effect of varieties found non-significant. Different salinity levels produced significant effect on test weight. Protein content did not significantly influence by salinity levels. Various varieties of chickpea gave significant result on various bio-chemical parameters like proline content, RWC, chlorophyll a, chlorophyll $\mathrm{b}$ and total chlorophyll content at 45 DAS. The proline content increased with increasing level of salinity. Significantly higher proline content $\left(1.14 \mu\right.$ mole $\mathrm{g}^{-1}$ of fresh weight) was recorded under application of $8.0 \mathrm{dS} \mathrm{m}^{-1}\left(\mathrm{~S}_{4}\right)$ saline irrigation water. The interaction effect of varieties and salinity gave non-significant result on that parameters.
\end{abstract}

Keywords: Saline irrigation water, yield, quality, biochemical parameter, chickpea, Cicer arietinum L.

\section{Introduction}

Chickpea (Cicer arietinum L.) is a member of family Fabaceae that is widely cultivated for its typically yellow-brown, pea-like seeds. The name chickpea also used for these edible seeds, which form in short pods and are popular in various cuisines. Chickpea is the fourth largest grain legume crop in the world with a total production of 13.12 million tons from an area of 13.57 million hectare and productivity $967 \mathrm{~kg} / \mathrm{ha}$. Major chickpea producing countries include India, Australia, Pakistan, Myanmar, Ethiopia, Turkey, Iran, Mexico, USA, Canada, Russian Federation and Tanzania (Anonymous, 2016) ${ }^{[1]}$. About 90 per cent of chickpea in the world is grown under rainfed conditions, where drought is one of the major constraints, limiting its production (Randhawa et al., 2014). India is the largest producer of chickpea contributing more than 75 per cent of the world production. In India, during 2015-16 chickpea was grown in an area of 8.35 million hectare with a production 7.17 million tons and productivity of 859 kg/ha. In India, Madhya Pradesh, Rajasthan, Maharashtra, Andhra Pradesh, Karnataka, Uttar Pradesh, Gujarat and Chhattisgarh are the major chickpea producing states contributing more than $95 \%$ to the total chickpea production. In Gujarat, during 2015-16 it was grown in area of 0.12 million hectare with a production 0.15 million tons and productivity $1330 \mathrm{~kg} / \mathrm{ha}$ (Anonymous, 2016) ${ }^{[1]}$.

Salinity in coastal groundwater is a widespread problem in many parts of India and Gujarat. Extend of saline area in Gujarat is 12.18 lakh ha. Main causes of increase in salinity on the coastal plain may be due to individual or combined effects of inherent salinity, tidal effect, irrigation by saltwater and by sea-water intrusion due to extensive pumping. Junagadh coastal area is one of the salinity affected areas mainly due to sea-water intrusion from last two-three decades.

Salinity stress delays the onset, reduces the rate and increases the dispersion of germination events, resulting in reduced plant growth and crop yield. Soil salinity adversely affects plant growth and development. 
Worldwide, about one-third of irrigated arable land is already affected and that level is still rising (Laz of and Bernstein, 1999) ${ }^{[10]}$. An excess of soluble salts in the soil leads to osmotic stress, which results in specific ion toxicity and ionic imbalances and the consequences of these can be plant demise (Rout and Shaw, 2001) ${ }^{[12]}$. Increasing crop salt tolerance is a highly attractive approach to overcoming the salinity threat. The need of the hour is to explore and select salt-tolerant genotypes within a species in comparison to relatively saltsensitive ones through conventional selection and breeding techniques.

\section{Materials and methods}

A bulk of surface soil sample from depth of 0-20 cm was collected from plot no-36 (Sagadividi farm) of Junagadh Agricultural University, Junagadh. Soil was air dried, powdered using wooden mortar and pestle, passed through a 2 mm sieve and mixed thoroughly. The bulk of soil was taken carefully in the laboratory for pot experiment. All necessary precaution was taken to avoid contamination from extraneous sources. The soil was analyzed for physico-chemical characteristics. The soil of the experimental plot was silty clayey in texture and alkaline in reaction with $\mathrm{pH} 8.0$, EC $0.58 \mathrm{dS} \mathrm{m}{ }^{-1}, \mathrm{CaCO}_{3} 31.05 \%$ and CEC $36.2 \mathrm{cmol}\left(\mathrm{p}^{+}\right) \mathrm{kg}^{-1}$. The soil was medium in available nitrogen $\left(242 \mathrm{~kg} \mathrm{ha}^{-1}\right)$, medium in available phosphorus (34.20 $\mathrm{kg} \mathrm{ha}^{-1}$ ), high in available potassium (298 $\left.\mathrm{kg} \mathrm{ha}^{-1}\right)$ and high in available sulphur (23.50 mg kg-1). Micro nutrient status was medium in available iron $\left(6.25 \mathrm{mg} \mathrm{kg}^{-1}\right)$, low in available zinc $(0.45 \mathrm{mg}$ $\left.\mathrm{kg}^{-1}\right)$, high in available manganese $\left(15.20 \mathrm{mg} \mathrm{kg}^{-1}\right)$ and high in available copper $\left(1.25 \mathrm{mg} \mathrm{kg} \mathrm{kg}^{-1}\right)$. Factorial Completely Randomization Design (CRD) with three replications was used to carry out the present investigations. The experiment consists of 20 treatments combinations comprising four levels of salinity and five levels of varieties. Four levels of salinity $\mathrm{S}_{1}-<2 \mathrm{dSm}{ }^{-1}, \mathrm{~S}_{2}-4 \mathrm{dSm}^{-1}, \mathrm{~S}_{3}-6 \mathrm{dSm}^{-1}, \mathrm{~S}_{4}-8 \mathrm{dSm}{ }^{-1}$ and five levels of varieties $V_{1^{-}}$GG-1, $V_{2^{-}}$GJG-3, $V_{3}-G G-5, V_{4^{-}}$ GJG-6, $V_{5^{-}}$Dahod Yellow, were taken in the present investigation. All sixty pots were filled with each soil bulk of $15 \mathrm{~kg}$. The required quantity of $\mathrm{N} @ 20 \mathrm{~kg} \mathrm{ha}^{-1}$ and $\mathrm{P}_{2} \mathrm{O}_{5} @$ $40 \mathrm{~kg} \mathrm{ha}^{-1}$ applied to all the pots as basal dose in the form of urea and DAP, respectively. Eight seeds of chick pea were sown in each pot at a depth of 2 to $3 \mathrm{~cm}$ on the $10^{\text {th }}$ November 2016. Only the required quantity of water was applied to avoid leaching during first and second irrigations. A week after germination five plants per each pot were maintained under normal practices. When crop required irrigation, the pots were uniformly irrigated with saline water as per treatments throughout the growing season. Other intercultural operations were followed as and when necessary. The crop was grown to maturity and observations on plant height, number of branches per plant, number of pods per plant, number of seeds per pod, root: shoot ratio, seed yield and straw yield were recorded. The statistical analysis of data of the characters studied by the investigation through the procedure appropriate to the design of the experiment.

\section{Result and discussion}

On the basis of results, the chickpea variety GJG-6 showed significantly higher values of yield, quality parameters (test weight) and bio-chemical parameters (proline, chlorophyll a, $\mathrm{b}$ and total chlorophyll) content at $\mathrm{S}_{1^{-}}<2 \mathrm{dSm}^{-1}$ salinity level among the different varieties and salinity levels.

\section{Seed yield}

The seed yield was significantly influence by different varieties of chickpea. Significantly higher value of seed yield (12.28 g plant $^{-1}$ ) was registered with variety $\mathrm{V}_{4}$ (GJG-6), and it was remain statistically at par with variety $\mathrm{V}_{1}(\mathrm{GG}-1)$ with value of $11.88 \mathrm{~g} \mathrm{plant}^{-1}$. The value of seed yield decreasing with increasing the level of saline irrigation water. Significantly higher seed yield (15.29 $\left.\mathrm{g} \mathrm{plant}^{-1}\right)$ was recorded under application of $<2.0 \mathrm{dS} \mathrm{m} \mathrm{m}^{-1}\left(\mathrm{~S}_{1}\right)$ saline irrigation water. While lowest seed yield was recorded under application of 8.0 $\mathrm{dS} \mathrm{m} \mathrm{m}^{-1}\left(\mathrm{~S}_{4}\right)$ saline irrigation water. The interaction effect of salinity level and variety was found significant in relation to seed yield. The highest seed yield $\left(15.91 \mathrm{~g} \mathrm{plant}^{-1}\right)$ was

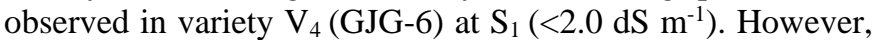
it was remain at par with variety $\mathrm{V}_{1}$ (GG-1), $\mathrm{V}_{2}$ (GJG-3) and $\mathrm{V}_{3}(\mathrm{GG}-5)$ at $\mathrm{S}_{1}\left(<2.0 \mathrm{dS} \mathrm{m} \mathrm{m}^{-1}\right)$. The lowest seed yield $(3.97 \mathrm{~g}$ plant $^{-1}$ ) was observed in $V_{5}$ (Dahod Yellow) under $S_{4}(8.0 \mathrm{dS}$ $\left.\mathrm{m}^{-1}\right)$. It means $\mathrm{V}_{5}$ is more affected by salinity level as compared to other varieties. Increasing salinity of irrigation water decrease in seed yield may be due to accumulation of salts in root zone affects plant performance through the development of water deficit and the disruption of ion homeostasis (Munns, 2002).

\section{Stalk yield}

Stalk yield after harvest was considerably influenced by different varieties of chickpea. Significantly higher value of stalk yield (20.55 $\left.\mathrm{g} \mathrm{plant}^{-1}\right)$ was recorded with variety $V_{4}$ (GJG-6). The stalk production was significantly affected by increasing salinity levels. Results data showed that stalk yield per plant decreased with increased salinity. The highest stalk yield $\left(20.50 \mathrm{~g} \mathrm{plant}^{-1}\right)$ was observed in $\left(\mathrm{S}_{1}\right)<2.0 \mathrm{dS} \mathrm{m} \mathrm{m}^{-1}$ and the lowest $\left(12.10 \mathrm{~g}\right.$ plant $\left.^{-1}\right)$ were recorded at $\left(\mathrm{S}_{4}\right) 8.0 \mathrm{dS} \mathrm{m}^{-1}$. The interaction effect of varieties and salinity level in relation to stalk yield also reported significant. The highest stalk yield (23.72 $\mathrm{g} \mathrm{plant}^{-1}$ ) was observed in $\mathrm{V}_{4}$ (GJG-6) which was remain statistically at par with $\mathrm{V}_{1}$ (GG-1) under irrigation water of $\left(\mathrm{S}_{1}\right)<2.0 \mathrm{dS} \mathrm{m} \mathrm{m}^{-1}$ and variety $\mathrm{V}_{4}$ (GJG-6) under irrigation water of $\left(\mathrm{S}_{2}\right) 4.0 \mathrm{dS} \mathrm{m} \mathrm{m}^{-1}$. While, lowest stalk yield $\left(8.62 \mathrm{~g} \mathrm{plant}^{-1}\right.$ ) was observed in $\mathrm{V}_{5}$ (Dahod Yellow) at salinity level $\left(\mathrm{S}_{4}\right) 8.0 \mathrm{dS} \mathrm{m}^{-1}$ of irrigation water. Reduce stalk per plant under saline condition might be due to inhibited photosynthesis under a salinity stress that causes less amount of nutrient uptake by the plant (Babu and Thirumurugan, 2001).

\section{Quality parameters \\ Test weight-100 seeds}

The effect of various chickpea varieties were affected significantly on test weight - 100 seeds. The highest test weight (18.11) was observed in $\mathrm{V}_{1}$ (GG-1), which remain statistically at par with $\mathrm{V}_{4}$ (GJG-6) and lowest test weight (17.48) was observed in $V_{5}$ (Dahod Yellow) and $V_{3}$ (GG-5). Test weight - 100 seed was considerably affected by increasing salinity levels. Significantly the highest value of test weight $(20.80 \mathrm{~g})$ observed in $\left(\mathrm{S}_{1}\right)<2.0 \mathrm{dS} \mathrm{m} \mathrm{m}^{-1}$ and lowest value (14.53) observed in $\left(\mathrm{S}_{4}\right) 4.0 \mathrm{dS} \mathrm{m} \mathrm{m}^{-1}$. The interaction effect of variety and salinity was resulted non-significant with regarding to test weight - 100 seeds in chickpea. Salinity stress at pod filling stage can cause a decrease in the photosynthate mobilization to grains and thereby decreasing grain weight. Ghassemi-Golezani et al. (2009) ${ }^{[7]}$ reported that grain filling duration decreased with increasing salinity which resulted in decreasing final grain weight. 


\section{Protein content}

Protein content of seed did not influence significantly by different varieties of chickpea but protein content (22.38) was observed high with variety $\mathrm{V}_{4}$ (GJG-6) as compared to other varieties of chickpea. Application of saline irrigation water produced non-significant effect on protein content in seeds of chickpea. However, decreased in protein content (24.96 to 18.16) observed with increasing salinity level from $<2.0$ to $8.0 \mathrm{dS} \mathrm{m} \mathrm{m}^{-1}$. The interaction effect of variety and salinity was found non-significant with concerning to protein content of seed in chickpea. The decrease in protein content under salinity stress may be ascribed to decreased protein synthesis or increased hydrolysis of protein (Brady et al. 1984) ${ }^{[4]}$.

\section{Bio-chemical parameters Proline content}

The results indicated that the proline content in leaves of chickpea at 45 DAS was significantly affected by different varieties and higher proline content $\left(1.13 \mu\right.$ mole $\mathrm{g}^{-1}$ of fresh weight) was noted with variety $\mathrm{V}_{4}$ (GJG-6) as compared to other tested varieties of chickpea. The calculation of proline content increased with increasing level of salinity. Significantly higher proline content $\left(1.14 \mu\right.$ mole $\mathrm{g}^{-1}$ of fresh weight) was recorded under application of $8.0 \mathrm{dS} \mathrm{m}^{-1}\left(\mathrm{~S}_{4}\right)$ saline irrigation water. The interaction effect of varieties and salinity levels was found significant on the proline content. The highest proline content $\left(1.36 \mu\right.$ mole $\mathrm{g}^{-1}$ of fresh weight)

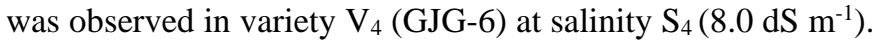
The lowest proline content was observed in $\mathrm{V}_{3}(\mathrm{GG}-5)$ under $\mathrm{S}_{1} \quad\left(<2.0 \mathrm{dS} \mathrm{m}^{-1}\right)$. Higher value of proline content was observed in chickpea variety GJG-6 at 45 DAS as compared remaining tested varieties in irrespective of salinity levels. Proline is a particular osmolyte in plants, increasing rapidly under reduced water levels and assists the plants to preserve cell turgor (Bidabadi et al. 2012) ${ }^{[3]}$.

\section{Relative water content (RWC)}

A perusal of the data revealed that different varieties of chickpea significantly influenced RWC of chickpea leaves at 45 DAS. Significantly higher value of RWC $(63.82 \%)$ was recorded with variety $\mathrm{V}_{4}$ (GJG-6) and it was statistically at par with $\mathrm{V}_{2}(\mathrm{GJG}-3)$. Application of $<2.0 \mathrm{dS} \mathrm{m} \mathrm{m}^{-1}\left(\mathrm{~S}_{1}\right)$ saline irrigation water, gave significantly higher value of RWC $(66.19 \%)$ and $8.0 \mathrm{dS} \mathrm{m}^{-1}$ gave lowest value of RWC (58.29 $\%)$. The combined effect of variety and salinity was not nonfound significant on RWC of chickpea. The relative water content decreases under salinity stress conditions (Srivasta et al. 1998, Katerji et al. 2003 and Kaya et al. 2003) ${ }^{[8,9]}$.

\section{Chlorophyll a content}

Chlorophyll a content in leaves influenced significantly among the varieties of chickpea. The highest chlorophyll a (7.78 $\mathrm{mg} \mathrm{g}^{-1}$ of fresh weight) content of chickpea leaves was recorded in $\mathrm{V}_{4}$ (GJG-6) and lowest content of chlorophyll a observed with $\mathrm{V}_{2}$ (GJG-3) with value of $6.37 \mathrm{mg} \mathrm{g}^{-1}$ of fresh weight. The valuation of chlorophyll a content of chickpea leaves decreasing with increasing level of salinity. Significantly higher chlorophyll a content $\left(7.62 \mathrm{mg} \mathrm{g}^{-1}\right.$ of fresh weight) was recorded under application $<2.0 \mathrm{dS} \mathrm{m} \mathrm{m}^{-1}\left(\mathrm{~S}_{1}\right)$ saline irrigation water and at par with $4.0 \mathrm{dS} \mathrm{m}^{-1}\left(\mathrm{~S}_{2}\right)$, while lowest content of chlorophyll a (5.22 $\mathrm{mg} \mathrm{g}^{-1}$ of fresh weight) observed with application of irrigation water having EC 8.0 $\mathrm{dS} \mathrm{m}^{-1}\left(\mathrm{~S}_{4}\right)$. The interaction effect of variety and salinity levels was found significant in respect to chlorophyll a content of chickpea leaves. The highest chlorophyll a $(8.35 \mathrm{mg}$ $\mathrm{g}^{-1}$ of fresh weight) was observed in $\mathrm{V}_{4}(\mathrm{GJG}-6)$ at $\mathrm{S}_{1}(<2.0 \mathrm{dS}$ $\mathrm{m}^{-1}$ ) which was statistically similar to that of $\mathrm{V}_{1}(\mathrm{GG}-1) \mathrm{X} \mathrm{S}_{1}$ $\left(<2.0 \mathrm{dS} \mathrm{m}^{-1}\right), \mathrm{V}_{3}(\mathrm{GG}-5) \mathrm{X} \mathrm{S}_{1}\left(<2.0 \mathrm{dS} \mathrm{m}^{-1}\right), \mathrm{V}_{4}(\mathrm{GJG}-6) \mathrm{X}$ $\mathrm{S}_{2}\left(4.0 \mathrm{dS} \mathrm{m} \mathrm{m}^{-1}\right), \mathrm{V}_{1}(\mathrm{GG}-1) \mathrm{X} \mathrm{S}_{2}\left(4.0 \mathrm{dS} \mathrm{m}^{-1}\right)$ and $\mathrm{V}_{4}$ (GJG-6) $\mathrm{X} \mathrm{S}_{3}\left(4.0 \mathrm{dS} \mathrm{m}^{-1}\right)$. The lowest chlorophyll a $\left(1.44 \mathrm{mg} \mathrm{g}^{-1}\right.$ of Fresh weight) was observed in $\mathrm{V}_{3}$ (GG-5) under $8.0 \mathrm{dS} \mathrm{m}^{-1}$ $\left(\mathrm{S}_{4}\right)$. Beinsan (2009) ${ }^{[2]}$ reported that decrease in leaf's chlorophyll content was due to increase in activity of chlorophyll destroying enzyme named chlorophyllase enzyme that would lead to destruction in chlorosplast and instability of protein complexity of pigments.

\section{Chlorophyll b content}

The chlorophyll b content of chickpea leaves at 45 DAS varied significantly among the tested varieties of chickpea. The highest chlorophyll b (20.48 $\mathrm{mg} \mathrm{g}^{-1}$ of fresh weight) was registered with $\mathrm{V}_{4}$ (GJG-6) and was statistically at par with $\mathrm{V}_{1}$ (GG-1). The chlorophyll b content was significantly affected by different salinity levels. Results indicated that chlorophyll b content decreased with increasing salinity (Table 4.3.1). The highest chlorophyll b (22.56 $\mathrm{mg} \mathrm{g}^{-1}$ of fresh weight) observed in salinity level $\left(\mathrm{S}_{1}\right)<2.0 \mathrm{dS} \mathrm{m} \mathrm{m}^{-1}$. The lowest chlorophyll b $\left(16.95 \mathrm{mg} \mathrm{g}^{-1}\right.$ of fresh weight) observed in salinity level $\left(\mathrm{S}_{4}\right)$ $8.0 \mathrm{dS} \mathrm{m}^{-1}$. The highest chlorophyll b $\left(23.66 \mathrm{mg} \mathrm{g}^{-1}\right.$ of fresh weight) was observed in $\mathrm{V}_{4}$ (GJG-6) at $\mathrm{S}_{1}\left(<2.0 \mathrm{dS} \mathrm{m} \mathrm{m}^{-1}\right)$, which was statistically par with all four varieties $\mathrm{V}_{1}(\mathrm{GG}-1)$, $\mathrm{V}_{2}$ (GJG-3), $\mathrm{V}_{3}$ (GG-5) and $\mathrm{V}_{5}$ (Dahod Yellow) at $\mathrm{S}_{1}(<2.0 \mathrm{dS}$ $\mathrm{m}^{-1}$ ) salinity level and also at par with $\mathrm{V}_{4}$ (GJG-6) at $\mathrm{S}_{2}(4.0$ $\mathrm{dS} \mathrm{m}^{-1}$ ) salinity level. The results are in conformity with those reported by Garg and Singla (2004) ${ }^{[6]}$ in chickpea.

\section{Total chlorophyll content}

The total chlorophyll content was significantly influenced by the varieties of chickpea. The total chlorophyll was recorded higher with variety $\mathrm{V}_{4}$ (GJG-6) with values of $28.25 \mathrm{mg} \mathrm{g}^{-1}$ of fresh weight as compared to other varieties of chickpea. The result indicated that saline irrigation water applications at various levels significantly influenced the total chlorophyll (30.19 $\mathrm{mg} \mathrm{g}^{-1}$ of fresh weight) which was recorded higher under applications of $<2.0 \mathrm{dS} \mathrm{m}^{-1}\left(\mathrm{~S}_{1}\right)$ saline irrigation water. The highest total chlorophyll (32.01 $\mathrm{mg} \mathrm{g}^{-1}$ of fresh weight) was observed in $\mathrm{V}_{4}$ (GJG-6) at $\mathrm{S}_{1}\left(<2.0 \mathrm{dS} \mathrm{m} \mathrm{m}^{-1}\right)$, which was statistically similar to that of $\mathrm{V}_{1}(\mathrm{GG}-1) \mathrm{X} \mathrm{S}_{1}\left(<2.0 \mathrm{dS} \mathrm{m}^{-1}\right)$, $\mathrm{V}_{3}(\mathrm{GG}-5) \mathrm{X} \mathrm{S}_{1}\left(<2.0 \mathrm{dS} \mathrm{m}^{-1}\right)$ and $\mathrm{V}_{4}(\mathrm{GJG}-6) \mathrm{X} \mathrm{S}_{2}\left(4.0 \mathrm{dS} \mathrm{m}^{-}\right.$ $\left.{ }^{1}\right)$. The lowest total chlorophyll (18.94 $\mathrm{mg} \mathrm{g}^{-1}$ of fresh weight) was observed in $\mathrm{V}_{3}(\mathrm{GG}-5) \times \mathrm{S}_{4}\left(8.0 \mathrm{dS} \mathrm{m} \mathrm{m}^{-1}\right)$ treatment combination. The above study has revealed that salt stress resulted in a general decline in chlorophyll content in all the cultivars of chickpea studied. Djanaguiraman and Ramadass (2004) have reported that Chlorophyll b showed higher level of reduction in comparison to chlorophyll a.

\section{Conclusion}

On the basis of results, the chickpea variety GJG-6 showed significantly higher values of yield (seed and stalk), quality parameters (test weight), bio-chemical parameters (proline, chlorophyll a, b and total chlorophyll) at EC $\left(<2 \mathrm{dS} \mathrm{m}^{-1}\right)$ salinity levels. Based on the result, it can be concluded that the variety $\mathrm{V}_{4}$ (GJG-6) was found the tolerance chickpea cultivar responding to application of saline irrigation water. This variety (GJG-6) perform better with different salinity tolerance criteria. The yield of this variety is least sensitive to salinity as compared to remaining other varieties. Tolerance sequence order of chickpea varieties as $\left(\mathrm{V}_{4}\right)$ GJG-6> $\left(\mathrm{V}_{1}\right)$ GG-1 > $\left(\mathrm{V}_{2}\right)$ GJG-3 > $\left(\mathrm{V}_{3}\right)$ GG-5> $\left(\mathrm{V}_{5}\right)$ Dahod yellow against salinity in clay soil. 
Table 1: Effect of varieties and salinity on seed and stalk yield of chickpea

\begin{tabular}{|c|c|c|}
\hline Treatments & Seed yield $\left(\mathrm{g} \mathrm{plant}^{-1}\right)$ & Stalk yield (g plant $\left.{ }^{-1}\right)$ \\
\hline \multicolumn{3}{|c|}{ Variety $(\mathrm{V})$} \\
\hline $\mathrm{V}_{1}: \mathrm{GG}-1$ & 11.88 & 17.67 \\
\hline $\mathrm{V}_{2}: \mathrm{GJG}-3$ & 11.42 & 15.03 \\
\hline $\mathrm{V}_{3}: \mathrm{GG}-5$ & 11.06 & 15.11 \\
\hline $\mathrm{V}_{4}:$ GJG-6 & 12.28 & 20.55 \\
\hline V5: Dahod Yellow & 9.31 & 13.99 \\
\hline S.Em. \pm & 0.24 & 0.39 \\
\hline C.D. $(\mathrm{P}=0.05)$ & 0.69 & 1.11 \\
\hline \multicolumn{3}{|c|}{ Salinity (S) } \\
\hline $\mathrm{S}_{1}:<2.0 \mathrm{dS} \mathrm{m}^{-1}$ (tap water) & 15.29 & 20.50 \\
\hline $\mathrm{S}_{2}: 4.0 \mathrm{dS} \mathrm{m}^{-1}$ & 12.99 & 18.54 \\
\hline $\mathrm{S}_{3}: 6.0 \mathrm{dS} \mathrm{m}^{-1}$ & 9.85 & 14.74 \\
\hline $\mathrm{S}_{4}: 8.0 \mathrm{dS} \mathrm{m}^{-1}$ & 6.63 & 12.10 \\
\hline S.Em. \pm & 0.21 & 0.35 \\
\hline C.D. $(\mathrm{P}=0.05)$ & 0.61 & 1.00 \\
\hline \multicolumn{3}{|c|}{ V x S Interaction } \\
\hline S.Em. \pm & 0.48 & 0.78 \\
\hline C.D. $(\mathrm{P}=0.05)$ & 1.37 & 2.23 \\
\hline C.V.\% & 7.44 & 8.20 \\
\hline
\end{tabular}

Table 2: Interaction effect of varieties and salinity on seed yield $\left(\mathrm{g} \mathrm{plant}^{-1}\right)$ and straw yield $\left(\mathrm{g} \mathrm{plant}^{-1}\right)$ of chickpea

\begin{tabular}{|c|c|c|c|c|c|c|c|c|c|c|}
\hline \multicolumn{6}{|c|}{ Seed yield $\left(\mathrm{g}_{\text {plant }}{ }^{-1}\right)$} & \multicolumn{5}{|c|}{ Straw yield $\left(\mathrm{g} \mathrm{plant}^{-1}\right)$} \\
\hline & $\begin{array}{c}\mathrm{S}_{1}:<2.0 \mathrm{dS} \mathrm{m}^{-} \\
1 \text { (tap water) }\end{array}$ & $\begin{array}{l}S_{2}: 4.0 \\
d_{S} \mathbf{m}^{-1}\end{array}$ & $\mathrm{~S}_{3}: 6.0 \mathrm{dS} \mathrm{m}^{-1}$ & $\begin{array}{l}\mathrm{S}_{4}: \mathbf{8 . 0} \\
\mathrm{dS} \mathrm{m}^{-1}\end{array}$ & Mean & $\begin{array}{c}S_{1}:<2.0 \mathrm{dS} \mathrm{m}^{-} \\
1 \text { (tap water) }\end{array}$ & $\begin{array}{l}S_{2}: 4.0 \\
d^{\prime} ~ m^{-1}\end{array}$ & $S_{3}: 6.0 \mathrm{dS} \mathrm{m}^{-1}$ & $\begin{array}{l}\mathrm{S}_{4}: \mathbf{8 . 0} \\
\mathrm{dS} \mathrm{m}^{-1} \\
\end{array}$ & Mean \\
\hline $\mathrm{V}_{1}: \mathrm{GG}-1$ & 15.75 & 13.35 & 10.70 & 7.74 & 11.88 & 21.86 & 19.87 & 16.53 & 12.43 & 17.67 \\
\hline $\mathrm{V}_{2}: \mathrm{GJG}-3$ & 15.43 & 13.10 & 10.48 & 6.68 & 11.42 & 19.02 & 16.20 & 12.84 & 12.07 & 15.03 \\
\hline $\mathrm{V}_{3}:$ GG-5 & 15.15 & 12.64 & 9.92 & 6.52 & 11.06 & 18.68 & 16.63 & 14.60 & 10.53 & 15.11 \\
\hline $\mathrm{V}_{4}:$ GJG-6 & 15.91 & 13.58 & 11.41 & 8.23 & 12.28 & 23.72 & 22.14 & 19.49 & 16.84 & 20.55 \\
\hline $\mathrm{V}_{5}$ : Dahod Yellow & 14.23 & 12.29 & 6.74 & 3.97 & 9.31 & 19.21 & 17.89 & 10.25 & 8.62 & 13.99 \\
\hline Mean & 15.29 & 12.99 & 9.85 & 6.63 & & 20.50 & 18.54 & 14.74 & 12.10 & \\
\hline S.Em. \pm & 0.48 & & C.D. $(\mathrm{P}=0.05)$ & 1.37 & & S.Em. \pm & 0.78 & C.D. $(\mathrm{P}=0.05)$ & 2.2 & \\
\hline
\end{tabular}

Table 3: Effect of varieties and salinity on quality parameter of chickpea

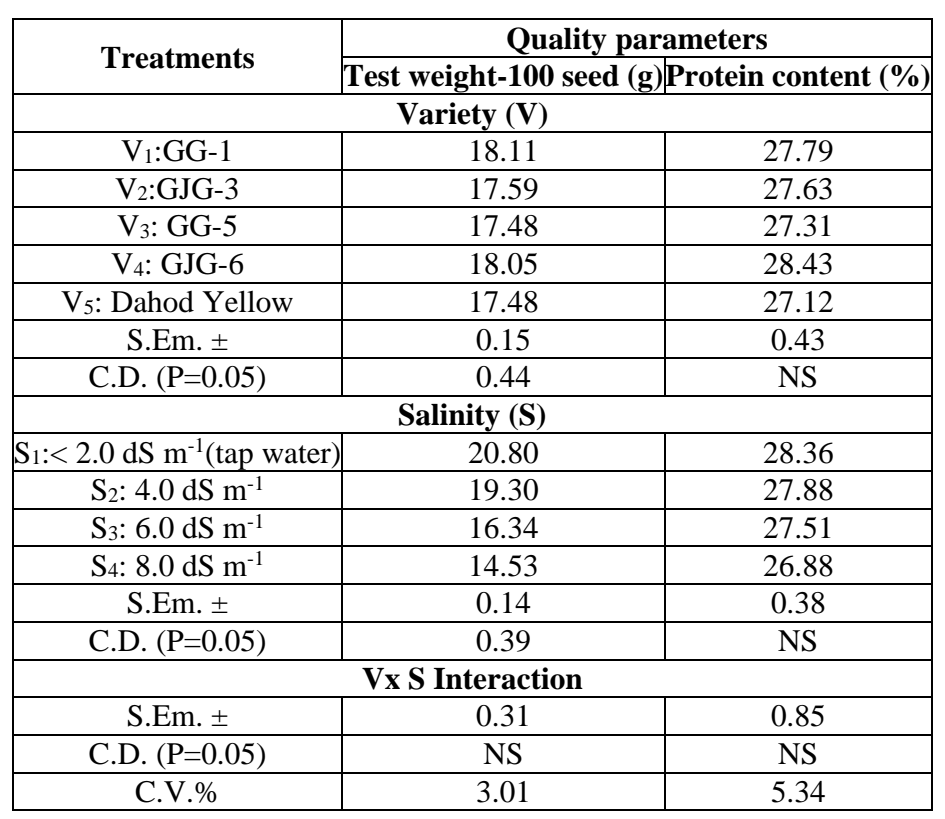

Table 4: Effect of varieties and salinity on biochemical parameters in leaves of chickpea at 45 DAS

\begin{tabular}{|c|c|c|c|c|c|}
\hline Treatments & Proline ( $\mu$ mole/gf.wt) & RWC (\%) & Chlorophyll a (mg/gf.wt) & Chlorophyll b (mg/gf.wt) & Total chlorophyll (mg/gf.wt) \\
\hline \multicolumn{6}{|c|}{ Variety (V) } \\
\hline $\mathrm{V}_{1}: \mathrm{GG}-1$ & 1.05 & 61.47 & 6.73 & 20.22 & 26.94 \\
\hline $\mathrm{V}_{2}: \mathrm{GJG}-3$ & 0.84 & 62.47 & 6.37 & 19.12 & 25.49 \\
\hline $\mathrm{V}_{3}: \mathrm{GG}-5$ & 0.80 & 59.88 & 6.38 & 17.90 & 24.28 \\
\hline $\mathrm{V}_{4}: \mathrm{GJG}-6$ & 1.13 & 63.82 & 7.78 & 20.48 & 28.25 \\
\hline $\mathrm{V}_{5}$ : Dahod Yellow & 0.85 & 62.25 & 6.38 & 17.51 & 23.88 \\
\hline S.Em. \pm & 0.02 & 0.51 & 0.18 & 0.44 & 0.46 \\
\hline C.D. $(\mathrm{P}=0.05)$ & 0.04 & 1.45 & 0.52 & 1.25 & 1.31 \\
\hline
\end{tabular}




\begin{tabular}{|c|c|c|c|c|c|}
\hline \multicolumn{6}{|c|}{ Salinity (S) } \\
\hline $\begin{array}{l}\mathrm{S}_{1}:<2.0 \mathrm{dS} \mathrm{m}^{-1} \\
\text { (tap water) }\end{array}$ & 0.60 & 66.19 & 7.62 & 22.56 & 30.19 \\
\hline $\mathrm{S}_{2}: 4.0 \mathrm{dS} \mathrm{m}^{-1}$ & 0.92 & 62.66 & 7.29 & 19.17 & 26.46 \\
\hline $\mathrm{S}_{3}: 6.0 \mathrm{dS} \mathrm{m}^{-1}$ & 1.07 & 60.76 & 6.78 & 17.49 & 24.27 \\
\hline $\mathrm{S}_{4}: 8.0 \mathrm{dS} \mathrm{m}^{-1}$ & 1.14 & 58.29 & 5.22 & 16.95 & 22.16 \\
\hline S.Em. \pm & 0.01 & 0.45 & 0.16 & 0.39 & 0.41 \\
\hline C.D. $(\mathrm{P}=0.05)$ & 0.04 & 1.35 & 0.46 & 1.12 & 1.17 \\
\hline \multicolumn{6}{|c|}{ Vx S Interaction } \\
\hline S.Em. \pm & 0.03 & 1.01 & 0.36 & 0.87 & 0.91 \\
\hline C.D. $(\mathrm{P}=0.05)$ & 0.09 & NS & 1.04 & 2.50 & 2.61 \\
\hline C.V.\% & 5.60 & 2.84 & 9.36 & 7.96 & 6.15 \\
\hline
\end{tabular}

Table 5: Interaction effect of varieties and salinity on proline ( $\mu$ mole/gf.wt) and chlorophyll a (mg/gf.wt) of chickpea

\begin{tabular}{|c|c|c|c|c|c|c|c|c|c|c|}
\hline \multicolumn{6}{|c|}{ proline ( $\mu$ mole/gf.wt) } & \multicolumn{5}{|c|}{ chlorophyll a (mg/gf.wt) } \\
\hline & \begin{tabular}{|c|}
$\mathrm{S}_{1}:<2.0 \mathrm{dS} \mathrm{m}^{-}$ \\
1 (tap water) \\
\end{tabular} & $\begin{array}{l}S_{2}: 4.0 \\
d_{S} ~ m^{-1}\end{array}$ & $S_{3}: 6.0 \mathrm{dS} \mathrm{m}^{-1}$ & $\begin{array}{l}S_{4}: 8.0 \\
d S ~ m^{-1} \\
\end{array}$ & Mean & $\begin{array}{l}S_{1}:<2.0 \mathrm{dS} \mathrm{m}^{-} \\
1 \text { (tap water) }\end{array}$ & $\begin{array}{l}S_{2}: 4.0 \\
d S m^{-1}\end{array}$ & $S_{3}: 6.0 \mathrm{dS} \mathrm{m}^{-1}$ & $\begin{array}{l}S_{4}: 8.0 \\
\text { dS m } \\
\end{array}$ & Mean \\
\hline $\mathrm{V}_{1}$ :GG-1 & 0.67 & 1.11 & 1.16 & 1.25 & 1.05 & 8.13 & 7.43 & 6.75 & 4.59 & 6.73 \\
\hline $\mathrm{V}_{2}: \mathrm{GJG}-3$ & 0.49 & 0.80 & 1.01 & 1.05 & 0.84 & 7.08 & 7.12 & 6.67 & 4.62 & 6.37 \\
\hline $\mathrm{V}_{3}: \mathrm{GG}-5$ & 0.46 & 0.73 & 0.99 & 1.02 & 0.80 & 7.86 & 7.16 & 5.94 & 4.57 & 6.38 \\
\hline $\mathrm{V}_{4}:$ GJG-6 & 0.89 & 1.07 & 1.20 & 1.36 & 1.13 & 8.35 & 8.02 & 7.52 & 7.22 & 7.78 \\
\hline V5: Dahod Yellow & 0.48 & 0.90 & 0.98 & 1.04 & 0.85 & 6.69 & 6.71 & 7.01 & 5.08 & 6.38 \\
\hline Mean & 0.60 & 0.92 & 1.07 & 1.14 & & 7.62 & 7.29 & 6.78 & 5.22 & \\
\hline S.Em. \pm & \multicolumn{2}{|l|}{0.03} & C.D. $(\mathrm{P}=0.05)$ & \multicolumn{2}{|c|}{0.09} & S.Em. \pm & 0.36 & C.D. $(\mathrm{P}=0.05)$ & \multicolumn{2}{|c|}{1.04} \\
\hline
\end{tabular}

Table 6: Interaction effect of varieties and salinity on chlorophyll b (mg/gf.wt) and total chlorophyll (mg/gf.wt) of chickpea

\begin{tabular}{|c|c|c|c|c|c|c|c|c|c|c|}
\hline \multicolumn{6}{|c|}{ chlorophyll b (mg/gf.wt) } & \multicolumn{5}{|c|}{\begin{tabular}{|c|} 
total chlorophyll (mg/gf.wt) \\
\end{tabular}} \\
\hline & $\begin{array}{c}\mathrm{S}_{1}:<2.0 \mathrm{dS} \mathrm{m}^{-} \\
1 \text { (tap water) }\end{array}$ & $\begin{array}{l}S_{2}: 4.0 \\
d^{-1} ~ m^{-1}\end{array}$ & $\mathrm{~S}_{3}: 6.0 \mathrm{dS} \mathrm{m}^{-1}$ & \begin{tabular}{|l|}
$S_{4}: 8$. \\
dS $~ m^{-1}$
\end{tabular} & Mean & $\begin{array}{c}\mathrm{S}_{1}:<2.0 \mathrm{dS} \mathrm{m}^{-} \\
1 \text { (tap water) }\end{array}$ & $\begin{array}{l}S_{2}: 4.0 \\
d^{-1} m^{-1}\end{array}$ & $\mathrm{~S}_{3}: 6.0 \mathrm{dS} \mathrm{m}^{-1}$ & $\begin{array}{l}\text { S4: } 8.0 \\
\text { dS m-1 }\end{array}$ & Mean \\
\hline $\mathrm{V}_{1}: \mathrm{GG}-1$ & 23.32 & 20.51 & 17.51 & 19.53 & 20.22 & 31.45 & 27.94 & 24.27 & 24.12 & 26.94 \\
\hline $\mathrm{V}_{2}: \mathrm{GJG}-3$ & 21.43 & 18.29 & 16.52 & 20.23 & 19.12 & 28.51 & 25.41 & 23.19 & 24.86 & 25.49 \\
\hline $\mathrm{V}_{3}: \mathrm{GG}-5$ & 22.69 & 17.86 & 16.67 & 14.38 & 17.90 & 30.56 & 25.01 & 22.61 & 18.94 & 24.28 \\
\hline V $4:$ GJG-6 & 23.66 & 21.98 & 20.26 & 16.02 & 20.48 & 32.01 & 30.00 & 27.78 & 23.24 & 28.25 \\
\hline $\mathrm{V}_{5}$ : Dahod Yellow & 21.72 & 17.23 & 16.50 & 14.58 & 17.51 & 28.41 & 23.94 & 23.52 & 19.67 & 23.88 \\
\hline Mean & 22.56 & 19.17 & 17.49 & 16.95 & & 30.19 & 26.46 & 24.27 & 22.16 & \\
\hline S.Em. \pm & \multicolumn{2}{|l|}{0.87} & C.D. $(\mathrm{P}=0.05)$ & \multicolumn{2}{|c|}{2.50} & S.Em. \pm & 0.91 & C.D. $(\mathrm{P}=0.05)$ & \multicolumn{2}{|c|}{2.61} \\
\hline
\end{tabular}

\section{References}

1. Anonymous. 2016. E-pulses data book, Indian Institute of Pulses Research, Kanpur (www.iipr.res.in) Accessed on 29-10-2016.

2. Beinsan C, Camen D, Sumalan R, Babau M. Study concerning salt stress effect on leaf area dynamics and chlorophyll contein in four bean local landraces from Banat area. 44th Croatian \& 4th International Symposium on Agriculture, 16-20. (Editors Florijančic', T.;Luzaic', R.), 2009, 416-419.

3. Bidabadi SS, Meon S, Wahab Z, Subramaniam S, Mahmood M. In vitro selection and characterization of water stress tolerant lines among ethyl methanesulphonate (EMS) induced variants of banana (Musa spp., with AAA genome). Australian Journal Crop Science. 2012; 6:567-575.

4. Brady CJ, Gibson TS, Barlow EWR, Speirs J, Wyn Jones RG. Salt tolerance in plants. Ions, compatible organic solutes and the stability of plant ribosomes. Plant Cell Environment. 1984; 1:571-578.

5. Djanaguiraman M, Ramadass R. Effect of salinity on chlorophyll content of rice genotypes. Agriculture Science Digester. 2004; 24(3):178-181.

6. Garg N, Singla R Growth, photosynthesis, nodule nitrogen and carbon fixation in the chickpea cultivars under salt stress. Brazil Journal Plant Physiology. 2004; 16:137-146.

7. Ghassemi-Golezani K, Taifeh-Noori M, Oustan SH, Moghaddam M. Response of soybean cultivars to salinity stress. Journal Food, Agriculture Environment. 2009; 7:401-404.

8. Katerji N, Van Hoorn JW, Hamdy A, Mastrorilli M. Salinity effect on crop development and yield, analysis of salt tolerance according to several classification methods. Agricultural Water Management. 2003; 62:37-66.

9. Kaya MD, Ipek A. Effect of different soil salinity levels on germination and seedling growth of safflower (Cartha mustinctorius L.). Turk Journal of Agriculture. 2003; 27:221-227.

10. Lazof DB, Bernstein $\mathrm{N}$. The $\mathrm{NaCl}$ inhibition of shoot growth: The case for disturbed nutrition with special consideration of calcium. Advance Botany. Research. 1999; 29:113-189.

11. Randhawa N, Kaur J, Singh S, Singh I. Growth and yield in chickpea (Cicer arietinum L.) genotypes in response of water stress. African Journal Agriculture Research. 2014; 9(11):982-992.

12. Rout NP, Shaw BP. Salt tolerance in aquatic macrophytes: Ionic relation and interaction. Biologicaplantanum. 2001; 44:95-99.

13. Srivasta TP, Gupta SC, Lal P, Muralia PN, Kumar A. Effect of salt stress on physiological and biochemical parameters of wheat. Annual Arid Zone. 1998; 27:197204. 